УДК $631.453 ; 504.054$

\title{
ИСПОЛЬЗОВАНИЕ МЕТОДОВ БИОТЕСТИРОВАНИЯ ДЛЯ ОЦЕНКИ ЭКОЛОГИЧЕСКОГО СОСТОЯНИЯ ПОЧВОГРУНТОВ РЕКУЛЬТИВИРОВАННОГО КАРЬЕРА
}

\author{
Т.В. Бардина*, М.В. Чугунова, В.В. Кулибаба, В.И. Бардина \\ Санкт-Петербургский научно-исследовательский центр экологической безопасности \\ Российской академии наук, Санкт-Петербург Россия \\ *E-mail: bardinatv@mail.ru \\ Статья потупила в редакиию 30.01.2010; принята к публикации 05.06.2020
}

Рассмотрена возможность применения разных методов биотестирования для экотоксилогической оценки почвогрунтов объекта прошлого экологического ущерба. Такие почвогрунты содержат загрязняющие вещества неизвестного состава. Поэтому в схему экологического контроля почвогрунтов наряду с химическим анализом необходимо включать биологические исследования, в частности биотестирование. Различные тест-организмы отличаются по своей чувствительности к токсикантам. Поэтому для повышения точности оценки токсичности почвогрунтов необходимо применять серию биотестов с использованием тест-организмов из различных таксономических групп. Исследования проведены на территории карьера, расположенного в Приневской низменности (Ленинградская область) и образованного в результате добычи кирпичных глин. Карьер был рекультивирован путем засыпки суглинистым грунтом с использованием бытовых отходов. Это привело к образованию на территории вторичного очага загрязнения. С помощью стандартных физико-химических и химических методов в почвогрунтах были определены $\mathrm{pH}$, общая щелочность, удельная электропроводность, содержание валовых форм тяжелых металлов, нефтепродуктов и бенз(а)пирена. Экотоксикологическая оценка почвогрунтов проводилась с помощью элюатных и контактных методов биотестирования, в том числе авторской методики, включенной в Госреестр. В качестве тесторганизмов использовались рачки Daphnia magna, инфузории Paramecium caudatum, одноклеточная водоросль Chlorella vulgaris, пшеница Triticum aestivum, природный комплекс микроорганизмов, состояние которого оценивали по ферментативной активности почвы. Химико-аналитические исследования не выявили превышения содержания токсичных веществ в почвогрунтах над принятыми нормативами. Методы биотестирования оказались более чувствительными. С их помощью токсичность была обнаружена во всех почвогрунтах. Выявлены наиболее эффективные и чувствительные биотесты, пригодные для экологического контроля почвогрунтов карьеров по выработке глин.

Ключевые слова: биотестирование, экотоксиканты, тест-культура, биотест-система.

\section{THE USE OF BIOLOGICAL TESTING APPROACHES TO ASSESSING THE ECOLOGICAL CONDITIONS OF SOILS IN A RECLAIMED SURFACE MINE}

\section{T.B. Bardina*, M.V. Chugunova, V.V. Kulibaba, V.I. Bardina}

Saint-Petersburg Research Center of Environmental Safety, the Russian Academy of Science, Saint Petersburg, Russia *E-mail: bardinatv@mail.ru

The appropriateness has been evaluated of different approaches to biological testing of soils from sites that have accumulated the results of past environmental insults. Since such soils feature the presence of unknown pollutants, it is expedient to supplement the chemical control with the biological testing thereof. Organisms used in biological testing differ in their sensitivity to different pollutants. Therefore, it is reasonable to use test batteries comprising organisms from different taxonomic groups. The present study has been carried out in a former open mine territory located in Prinevskaya Depression (Leningrad Region). The mine was used sometimes ago to obtain clay for brick manufacturing. Thereafter, the mine pit was covered with a loamy soil contaminated with solid household waste. This resulted in the development of a secondary pollution focus. Standard physical and chemical methods were used to determine $\mathrm{pH}$, total alkalinity, specific conductivity, heavy metals, oils products and benzo(a)pyrene in soil samples obtained from the site. Biological testing was performed using eluting and contact approaches, including an original method approved by State Register. The test organisms were Daphnia magna water flee, Paramecium caudatum infusoria, Chlorella vulgaris alga, and Triticum aestivum wheat. Soil microorganism complex was assessed by soil enzymatic activities. Chemical and physical analyses did not reveal increases in pollutant markers above normative values. Biological testing proved to be more sensitive. Their use suggested that all soil samples were somewhat toxic. The most appropriate methods for testing former open clay mines have been selected.

Keywords: biological testing, environmental toxicants, test system.

\section{Введение}

При оценке экологических рисков загрязненного почвенного покрова учитывают данные не только химических исследований, но и экотоксикологических, проводимых с помощью биотестирования $[12,22,24]$. Биотестирование относится к интегральным методам оценки состояния природных сред, в том числе загрязненных почвогрунтов. В почвогрунтах объектов, где образовались очаги загрязнения со сложным составом токсикантов, содержится большое количество загрязняющих веществ неизвестного состава, обладающих кумулятивным токсическим эффектом, который не позволяет 
сделать достоверный экологический прогноз только на основе химических определений. В связи с этим в систему экологического контроля объектов окружающей среды вводится биотестирование, представляющее собой лабораторный метод оценки качества объекта с использованием тест-организма, который используется для выявления суммарной токсичности среды. Методы биотестирования в настоящее время стали весьма востребованными в экологическом мониторинге природных и техногенных сред [30]. С помощью методов биотестирования можно быстро и с минимальными затратами оценивать интегральную токсичность сложных природных объектов. Поэтому многие исследователи вступают за то, чтобы биотестирование наряду с химическими методами включать в систему природоохранной стратегии [2, 5, 17].

Известно, что различные тест-организмы отличаются по своей чувствительности к токсикантам. В связи с этим для повышения объективности исследования токсичности объекта применяют серию биотестов, в которых используют тесткультуры, относящиеся к различным таксономическим группам [25]. Кроме этого выявлено, что для адекватной оценки токсичности твердых объектов, к которым относится почвенный покров, применение методов только элюатного биотестирования (биотестирование водной вытяжки с использованием различных гидробионтов в качестве тест-организмов) недостаточно. Применение гидробионтов для тестирования позволяет оценить лишь опасность растворов, выщелачиваемых из образца, для пограничных экосистем [9]. Однако, когда надо установить токсичность твердого объекта, возникает необходимость применять и субстратное (иначе - контактное) биотестирование. Этот способ обеспечивает непосредственный контакт тест-организма с исследуемым образцом и таким образом позволяет установить уровень воздействия твердых загрязнителей $[16,17]$.

В настоящее время весьма актуальным является разработка новых методов биотестирования, а также выявление возможности применения разных биотест-систем с использованием тест-организмов из разных таксономических групп для точного установления экологического состояния конкретных объектов [27]. Для адекватной оценки экологического состояния почвогрунтов объектов прошлого (накопленного) экологического ущерба такие биотест-системы до сих пор не выявлены.

В связи с этим целью нашего исследования была разработка оптимального набора биотест-систем, с помощью которого можно адекватно и в короткие сроки оценить экологическое состояние почвогрунтов вторичных объектов прошлого экологического ущерба, таких как рекультивированные глинистые карьеры.

\section{Объект и методы исследования}

К числу объектов накопленного экологического ущерба на территории Северо-Запада Российской Федерации относятся рекультивированные с помощью твердых бытовых отходов глинистые карьеры. Несмотря на то, что почвогрунты этих образований могут представлять опасность для окружающей природной среды, изучение их интегральной экотоксичности методами биотестирования до сих пор не проводилось.

Объектами нашего исследования были почвогрунты, сформированные на территории карьера, расположенного на правобережье р. Невы в Приневской низменности и образованного в результате добычи кирпичных глин (рис. 1). После прекращения выработки глин была произведена его рекультивация путем засыпки суглинистым грунтом с использованием бытовых отходов. Это привело к тому, что на территории образовался вторичный очаг загрязнения, связанного с анаэробной ферментацией органического вещества отходов, в результате которой произошло восстановление соединений серы до сульфидов и появление токсичных соединений в дренажных стоках $[10,13]$.

Территория объекта отличалась заметной гетерогенностью рельефа, поэтому исследования проводились на 3 площадках площадью 25 м $^{2}$ каждая. Отбор проб почвогрунтов производился с глубин 0-5 и 5-20 см по ГОСТ 17.4.4.02-84.

Стандартные физико-химические и химические методы исследования почвогрунтов включали: определение рН потенциометрическим методом ${ }^{1}$, удельной электропроводности кондуктометрическим методом ${ }^{2}$, общей щелочности ${ }^{3}$, валовых форм тяжелых металлов масс-спектрометрическим методом ${ }^{4}$, а также содержания нефтепродуктов методом газовой хроматографии ${ }^{5}$ и бенз(а)пирена методом жидкостной хроматографии ${ }^{6}$.

Экотоксилогическую оценку почвогрунтов проводили с помощью элюатных и контактных методов биотестирования.

Для определения острой токсичности водных вытяжек из почв и почвогрунтов в целях мониторинга окружающей среды (элюатное биотестирование) наиболее часто используются рачки дафнии (Daphnia magna Straus) как высокочувствительные к поллютантам тест-организмы [28]. Биотестирование водных вытяжек из исследованных

\footnotetext{
${ }^{1}$ ГОСТ 26423-85.

2 Там же.

${ }^{3}$ ОСТ 46-52-76. Методы агрохимического анализа почв.

${ }^{4}$ ПНД Ф 16.1:2.3:3.11-98. Количественный химический анализ почв. Методика выполнения измерений содержания металлов в твердых объектах методом спектрометрии с индуктивно-связанной плазмой.

${ }^{5}$ МУК 4.1.1061-01. Хромато-масс-спектрометрическое определение летучих веществ в почве и отходах производства и потребления.

${ }^{6}$ ФР 1.31.2005. 01725. Методика выполнения измерений массовой доли бенз(а)пирена в почвах, грунтах и осадках сточных вод методом жидкостной хроматографии.
} 
почвогрунтов с помощью дафний проводили по аттестованной методике ${ }^{7}$. Методика основана на определении смертности дафний при воздействии токсических веществ, присутствующих в исследуемой среде, в сравнении с контрольной культурой в пробах, не содержащих токсических веществ (контроль). Критерием острой токсичности (Т) служит гибель 50\% и более дафний за 48 часов в исследуемой пробе при условии, что в контрольном эксперименте все рачки сохраняют свою жизнедеятельность. Данный биотест можно отнести к полнофункциональным, так как в нем используется такая необратимая реакция тест-организма, как смертность.

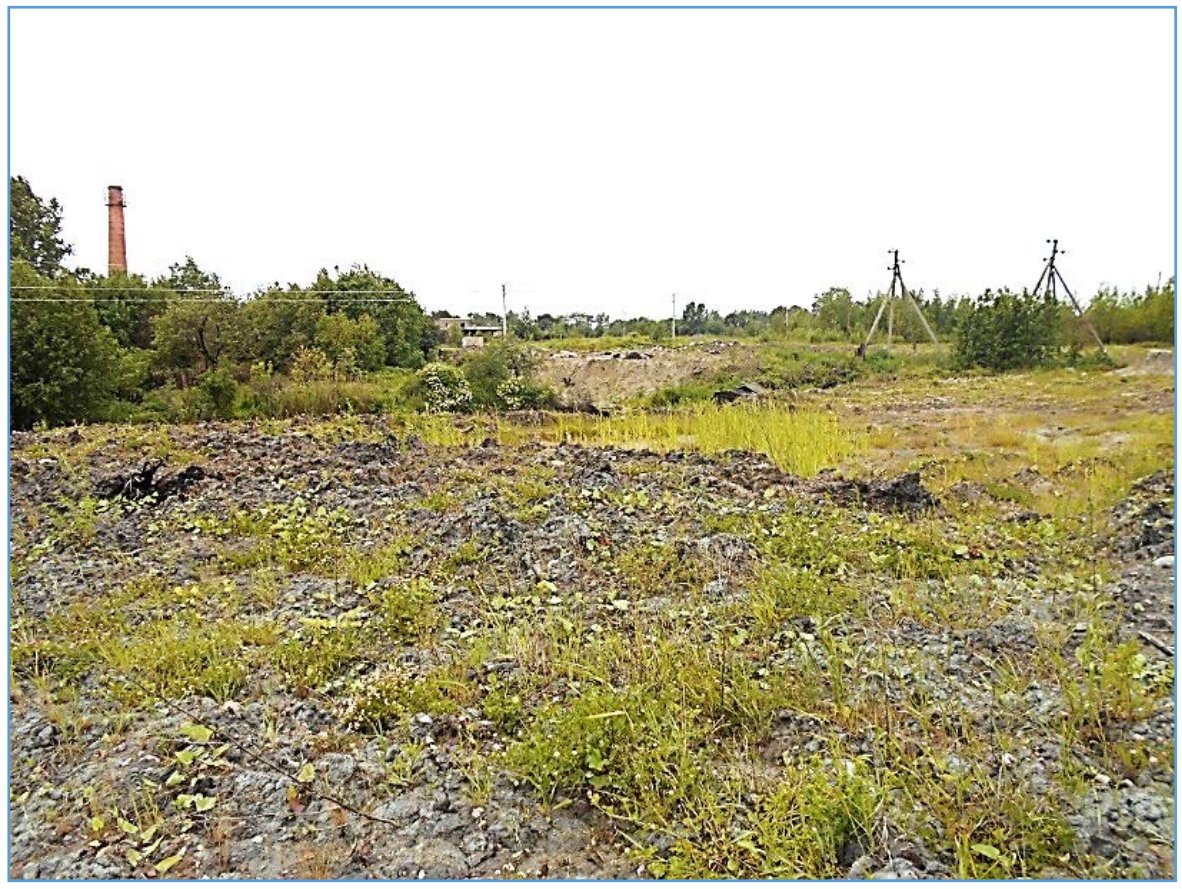

Рис. 1. Территория исследованного карьера

Достаточно распространенным тест-организмом элюатного биотестирования являются инфузории Paramecium caudatum в связи с тем, что их чувствительность к широкому кругу токсикантов весьма близка к чувствительности тканей человека и животных. Кроме этого инфузории широко распространены в пресных водоемах и принимают активное участие в круговороте веществ как консументы. Биотестирование испытуемых почвогрунтов на инфузориях было проведено инструментальным методом с применением прибора Биотестер- $2^{8}$. Данный метод прост и быстр в исполнении.

При элюатном биотестировании на инфузориях используют хемотаксическую реакцию, которая выражается в перемещении тест-организмов вдоль градиента концентрации химических веществ. Хемотаксическая реакция относится к поведенческим реакциям, более быстрым и чувствительным, чем биохимические и физиологические реакции дафний. Критерием токсичности на инфузориях служит индекс токсичности $(\mathrm{T})$ - безразмерная величина, принимающая значения от 0 до 1 в соответствии со степенью токсичности анализируемой пробы.

Определение острой токсичности почвогрунтов было проведено также с использованием одноклеточной зеленой протококковой водоросли хлорелла (Chlorella vulgaris Beijer) в качестве тест-культуры по аттестованной методике ${ }^{9}$. Методика основана на регистрации различий в оптической плотности тест-культуры водоросли хлорелла, выращенной на среде, не содержащей токсических веществ (контроль) и в тестируемых водных вытяжках (опыт), в которых эти вещества могут присутствовать. Данный биотест является скрининговым, так как в нем используется не летальная функция тест-организма, а функция замедления прироста водоросли под влиянием токсичных веществ, и проводится с использованием комплекта оборудования ЛаборБиоТест (ЛБТ). Измерение оптической плотности суспензии водоросли с помощью

\footnotetext{
${ }^{7}$ ПНД Ф Т 14.1:2:4.12-06. Методика определения токсичности питьевых, пресных природных и сточных вод, водных вытяжек из почв, осадков сточных вод и отходов по смертности дафний (Daphnia magma Straus).

${ }^{8}$ ПНД Ф Т 16.2:2.2-98. Методика определения токсичности проб почв, донных отложений и осадков сточных вод экспрессметодом с применением прибора «Биотестер». 2015.

${ }^{9}$ ПНД Ф Т 14.1:2:3:4.10-04. Методика измерений оптической плотности культуры водоросли хлореллы (Chlorella vulgaris Beijer) для определения токсичности питьевых, пресных природных и сточных вод, водных вытяжек из гоунтов, почв, осадков сточных вод, отходов производства и потребления. М., 2014.
} 
фотоэлектроколориметра (ИПС-03) позволяет оперативно контролировать изменение численности клеток в контрольном и опытном вариантах токсикологического эксперимента, проводимого в специализированном многокюветном культиваторе (КВМ-05). Критерием токсичности воды является снижение на 20\% и более (подавление роста) или увеличение на $30 \%$ и более (стимуляция роста) величины оптической плотности культуры водоросли, выращиваемой в течение 22 часов световой экспозиции на тестируемой воде по сравнению с ее ростом на контрольной среде, приготовленной на дистиллированной воде. Среднее значение оптической плотности вычисляют по результатам четырех параллельных определений. С целью выявления нетоксичного разбавления водных вытяжек готовится ряд разбавлений, кратных трем $(9,27,81,243,729)$.

Среди контактных биотестов при контроле экологического состояния почв наиболее эффективным считается фитотестирование, при котором в качестве тест-организма используются высшие растения [19]. Для лабораторного фитотестирования характерны быстрота и простота исполнения, экономичность, воспроизводимость и достоверность получаемых результатов.

Контактное фитотестирование изучаемых почвогрунтов проводили по методике, разработанной в НИЦЭБ РАН и включенной в Госреестр ${ }^{10}$. В наших исследованиях тест-культурой служили семена пшеницы мягкой (Triticum aestivum L). Определение степени острой фитотоксичности пробы проводилось на основании разработанной по двум показателям шкалы: по изменению всхожести семян $\left(N_{1}\right)$ и роста корней $\left(N_{2}\right)$ по сравнению с контрольным образцом. Контрольный образец согласно нашей включенной в ГОСТ методики представлял собой искусственно приготовленную почвенную смесь, сходную с исследуемыми пробами по гранулометрическому составу и содержанию гумуса. В связи с тем, что почвогрунт № 3 отличался от остальных образцов $(№ 1,2)$ по количеству органического вещества, при проведении контактных методов биотестирования использовали два контрольных субстрата. Контроль-1 для почвогрунтов площадок № 1 и 2 состоял из дерново-подзолистой суглинистой почвы и кварцевого песка. Контроль-2 для почвогрунта площадки № 3 был приготовлен из дерново-подзолистой суглинистой почвы и кварцевого песка с добавлением верхового торфа.

В качестве контроля использовали искусственно приготовленный почвогрунт, сходный с исследуемыми образцами по его гранулометрическому составу и содержанию гумуса. В данном случае применяли два контроля в связи с различными свойствами почвогрунта на площадках.

Для второго примененного нами контактного метода в качестве тест-организма использовали природный комплекс микроорганизмов, содержащийся непосредственно в исследованных почвах. Известно, что приоритетным показателем качества почв и почвогрунтов служит состояние произрастающих на них растений. Однако не менее значимым индикатором являются микроорганизмы. Это обусловлено той исключительно важной ролью, которую микробные сообщества играют в круговороте биогенных элементов в биосфере и в поддержании в почвах экологического равновесия. Кроме того, микроорганизмы являются чуткими индикаторами биологического состояния почв и почвогрунтов и могут служить оптимальными тест-культурами для биотестирования [18].

При оценке токсичности почв с помощью микроорганизмов обычно тестируют водную вытяжку (элюатный способ). Наиболее широко используемый элюатный микробиологический метод основан на фиксации изменений интенсивности бактериальной люминесценции тест-системой «Эколюм» на приборе «Биотокс-10» [8]. Кроме того, существуют методы биотестирования почвенных вытяжек, в основе которых лежит определение различных тест-функций почвенных цианобактерий $[4,20]$.

Используемые в настоящее время в России контактные микробные тесты основаны на оценке влияния загрязненного субстрата на искусственно внесенные в него тестовые микроорганизмы [3]. Однако в самих почвах и почвогрунтах содержится значительное количество жизнеспособной микрофлоры. Это позволяет использовать в целях экодиагностики в качестве тесткультуры природный комплекс микроорганизмов, содержащихся непосредственно в самих почвах.

Важнейшей экологической функцией микроорганизмов является их респираторная активность, иначе почвенное дыхание, которая представляет собой интегральный показатель напряженности протекающих в почвах деструкционных процессов, вызываемых микроорганизмами. Минерализация органических веществ с возвратом СО 2 в атмосферу является конечным звеном глобальной трофической цепи и осуществляется в почвенном покрове за счет деятельности гетеротрофных микроорганизмов. Чем интенсивнее микробиологические процессы в почве, тем больше она генерирует $\mathrm{CO}_{2}$. Около $90 \%$ образующейся из органических веществ углекислоты - микробного происхождения, и только 10\% приходятся на долю дыхания животных и человека [7].

В настоящее время почвенное дыхание считается одним из наиболее важных индикаторов состояния не только микробного комплекса почв, но и почвенной экосистемы в целом $[6,14]$. Он также широко используется при биондикации почв и почвогрунтов, формирующихся в зоне воздействия территорий складирования ТБО, с целью их экологической оценки $[15,17,29]$.

${ }^{10}$ ФР. 1.39.2006.02264. Методика выполнения измерений всхожести семян и длины корней проростков высших растений для определения токсичности техногенно-загрязненных почв. 
В связи с этим в данной работе использовали контактный микробный биотест, основанный на оценке ингибирования микробного дыхания загрязненными ТБО почвогрунтами. Критерий при оценке токсичности почвогрунтов определяли на основе статистически значимых изменений уровня их микробного (почвенного) дыхания по сравнению с контрольными субстратами. Почвенное дыхание устанавливали в контролируемых лабораторных условиях адсорбционным методом по интенсивности выделения $\mathrm{CO}_{2}$ почвогрунтами [23]. Контролем служила не загрязненная ТБО почва, аналогичная исследованным почвогрунтам по гранулометрическому составу и содержанию органического вещества. Образцы предварительно увлажняли дистиллированной водой до $60 \%$ ПВ и компостировали при комнатной температуре.

Важным показателем экологического состояния почв и почвогрунтов является их ферментативная активность, которую часто используют в качестве раннего диагностического показателя негативных изменений, происходящих в почве под влиянием антропогенных воздействий [26]. Почвенные ферменты поступают из микроорганизмов, водорослей, лишайников, высших растений и почвенной фауны. Снижение ферментативной активности в почве более чем на $30 \%$ свидетельствует о значительном нарушении ее качества [21]. Один из видов ферментативной активности почв обусловлен почвенными протеазами, катализирующими гидролитическое расщепление азотсодержащих органических соединений (белков и пептидов). Определение протеазной активности в почвогрунтах карьера проводили аппликационным методом с использованием непроявленной фотопленки [11]. Метод основан на фиксации биоразрушения эмульсионного слоя фотопленки, содержащего желатин, как источника азота для микробиоты. Степень разрушения желатинового слоя соответствует уровню протеазной активности в субстрате. Для определения ферментативной активности в лабораторных условиях метод Е.Н. Мишустина был модифицирован. Высокая чувствительность усовершенствованного метода была выявлена ранее при определении токсичности загрязненных почвогрунтов отвалов промышленных отходов [1]. Метод прост в исполнении и характеризуется высокой чувствительностью, что дает возможность включить его в систему субстратных (контактных) методов лабораторного биотестирования для целей экологического контроля загрязненных субстратов.

Все определения проводили в 4-кратной повторности; полученные результаты обрабатывали методом дисперсионного анализа с использованием программ MS Excel и Statistica 10. Достоверность различий между средними значениями сравнивалась с помощью критерия Стьюдента в варианте группировки выборок с наименее значимой разницей (Least Significant Difference, LSD) при уровне значимости 5\% (P <0,05). В таблицах приведены средние значения \pm стандартные отклонения, величины с разными буквами различаются достоверно.

\section{Результаты и обсуждение}

По результатам исследования физико-химических и химических свойств почвогрунтов, было установлено, что они имели нейтральную реакцию среды (pH 6,3-6,5), что является благоприятным для развития растений и микроорганизмов. Почвогрунты не засолены (удельная электропроводность колеблется в пределах 0,42-0,77 мСм, а общая щелочность составляет 0,20-0,60 ммоль-экв/100 г, что свидетельствует о незначительном присутствии бикарбонатных ионов. Превышение содержания тяжелых металлов над принятыми ПДК (ОДК) не выявлено. Содержание определенных органических токсикантов также не превышало соответствующие нормативы.

Элюатное биотестирование на тест-культуре дафний (Daphnia magna Straus) в остром эксперименте не выявило токсичности ни в одном из почвогрунтов (табл. 1).

Результаты биотестирования водных вытяжек на дафниях

\begin{tabular}{|l|c|c|c|c|}
\hline $\begin{array}{c}\text { № площадки, } \\
\text { глубина } \\
\text { отбора, см }\end{array}$ & $\begin{array}{c}\text { Число выживших рачков } \\
\text { за время экспозиции, 96 ч }\end{array}$ & $\begin{array}{c}\text { Число погибших } \\
\text { относительно } \\
\text { контроля, А (\%) }\end{array}$ & td & $\begin{array}{c}\text { Токсикологическая } \\
\text { характеристика } \\
\text { пробы }\end{array}$ \\
\hline Контроль & $10 \pm 0^{\text {a }}$ & - & - & - \\
\hline $1,0-5$ & $8,6 \pm 0,8^{b}$ & 14,3 & 1,63 & Нетоксичная \\
\hline $1,5-20$ & $10 \pm 0^{\text {a }}$ & 0 & 0,82 & Нетоксичная \\
\hline $2,0-5$ & $10 \pm 0^{\text {a }}$ & 0 & 0,82 & Нетоксичная \\
\hline $2,5-20$ & $8,6 \pm 0,8^{\mathrm{b}}$ & 14,3 & 1,63 & Нетоксичная \\
\hline $3,0-5$ & $10 \pm 0^{\text {a }}$ & 0 & 0,82 & Неооксичная \\
\hline $3,5-20$ & $10 \pm 0^{\text {a }}$ & 0 & 0,82 & Нетоксичная \\
\hline
\end{tabular}

Примечание: контроль - аквариумная вода; $\mathrm{td}$ - коэффициент достоверности.

Табл. 1

По результам биотестирования на инфузориях токсичность была зафиксирована только на площадке № 3 на глубине $0-5 \mathrm{~cm}$.

Результаты биотестирования на инфузориях (Paramecium caudatum) приведены в табл. 2.

Результаты биотестирования почвенных вытяжек с использованием водоросли хлорелла (Chlorella vulgaris Beijer) в качестве тест-культуры представлены в табл. 3. 
Табл. 2

Результаты биотестирования водных вытяжек на инфузориях

\begin{tabular}{|c|c|c|c|c|c|}
\hline \\
\hline $\begin{array}{c}\text { № } \\
\text { площадки }\end{array}$ & $\begin{array}{c}\text { Глубина, } \\
\text { см }\end{array}$ & $\begin{array}{c}\text { Среднее } \\
\text { показания } \\
\text { прибора } \\
\end{array}$ & $\begin{array}{c}\text { Среднее значение } \\
\text { индекса токсичности, } \\
\text { T } \\
\end{array}$ & td & $\begin{array}{c}\text { Группа } \\
\text { токсичности }^{* *}\end{array}$ \\
\hline Контроль* & - & $61,9 \pm 2,5^{\mathrm{a}}$ & - & - & - \\
\hline \multirow[t]{2}{*}{1} & $0-5$ & $38,4 \pm 1,8^{\mathrm{b}}$ & 0,38 & 1,88 & $\mathrm{I}$ \\
\hline & $5-20$ & $69,1 \pm 4,5^{\mathrm{a}}$ & 0,13 & 0,56 & $\mathrm{I}$ \\
\hline \multirow[t]{2}{*}{2} & $0-5$ & $49,5 \pm 4,6^{c}$ & 0,20 & 0,89 & I \\
\hline & $5-20$ & $41,4 \pm 1,0^{b}$ & 0,33 & 1,65 & $\mathrm{I}$ \\
\hline \multirow[t]{2}{*}{3} & $0-5$ & $37,0 \pm 3,3^{b}$ & 0,40 & 1,95 & II \\
\hline & $5-20$ & $49,3 \pm 3,8^{c}$ & 0,20 & 0,97 & I \\
\hline
\end{tabular}

Табл. 3

Результаты биотестирования водных вытяжек на зеленых водорослях

\begin{tabular}{|c|c|c|c|c|}
\hline $\begin{array}{c}\text { № } \\
\text { площадки }\end{array}$ & $\begin{array}{c}\text { Глубина } \\
\text { (см) }\end{array}$ & $\begin{array}{c}\text { Отклонение от } \\
\text { контроля (\%) }\end{array}$ & $\begin{array}{c}\text { Оценка } \\
\text { токсичности водной } \\
\text { вытяжки }\end{array}$ & $\begin{array}{c}\text { Величина токсической } \\
\text { кратности разбавления (ТКР) }\end{array}$ \\
\hline \multirow{2}{*}{1} & $0-5$ & $36^{\mathrm{a}}$ & Токсичная & 3 \\
\cline { 2 - 5 } & $5-20$ & $12^{\mathrm{b}}$ & Нетоксичная & 3 \\
\hline \multirow{2}{*}{2} & $0-5$ & $28^{\mathrm{c}}$ & Токсичная & 3 \\
\cline { 2 - 5 } & $5-20$ & $27^{\mathrm{c}}$ & Токсичная & 3 \\
\hline \multirow{2}{*}{3} & $0-5$ & $22^{\mathrm{d}}$ & Токсичная & 9 \\
\cline { 2 - 5 } & $5-20$ & $44^{\mathrm{ab}}$ & Токсичная & 3 \\
\hline
\end{tabular}

Из представленных данных следует, что только один образец, отобранный на площадке № 1 с глубины 5-20 см, был не токсичным по отношению к исследуемой тест-культуре. Во всех остальных образцах с использованием хлореллы была выявлена токсичность. В образцах с площадки № 1 (глубина 0-5 см), с площадки № 2 (глубина 0-5, 5-20), с площадки № 3 (глубина 0-5 см) токсический эффект исчезал уже при 3-кратном разбавлении. Наибольшая токсичность обнаружена в образце с площадки № 3 с глубины 5-20 см. Степень ингибирования роста водоросли этого образца под действием неразбавленной водной вытяжки составляла 44\%. Однако токсический эффект исчезал уже при 9-кратном разбавлении.

Таким образом, по отношению к хлорелле критерий токсичности превышен на площадках 1, 2, 3 в исследованных пробах в верхнем горизонте 0-5 см почвогрунта и в 2 пробах, отобранных с глубины 5-20 см. Однако с учетом небольшой степени разбавления (в 3 и 9 раз), в этих образцах можно фиксировать наличие лишь слабой токсичности по отношению к хлорелле.

Итак, среди гидробионтов, используемых при экотоксилогической оценке почвогрунтов рекультивируемого карьера, наиболее чувствительной к условиям среды тест-культурой оказалась хлорелла, значительно меньшей чувствительностью характеризовались инфузории. Использование рачков дафний оказалось неэффективным, так как они не реагировали на содержание предполагаемых токсикантов в водной вытяжке.

Результаты контактного фитотестирования на семенах пшеницы (Triticum aestivum L) представлены на рис. 2 и 3.

По признаку уменьшения всхожести семян пшеницы на почвогрунтах в сравнении с контролем были выявлены умеренная токсичность на глубине 5-20 см площадки № 1 (-30\%) и малая токсичность по всей глубине на площадке № 3 (20\%). В почвогрунте площадки № 2 токсичность не обнаружена.

По признаку длины корня в сравнении с контролем токсичность была установлена на площадке № 1: малая токсичность на глубине 0-5 см и умеренная токсичность на глубине 5-20 см (рис. 3). Таким образом, в результате контактного фитотестирования было выявлено наличие от малой до умеренной токсичности почвогрунтов на площадках № 1 и 3 .

Результаты субстратных микробных биотестов, представленные на рис. 4, показали, что наибольшей токсичностью для микробиоты среди исследованных субстратов характеризовался почвогрунт площадки № 1.

Так, респираторная активность микроорганизмов на глубине 5-20 см уменьшилась почти на 70\% по сравнению с чистой почвой, что почти в 2 раза превышает критический порог устойчивости почвенных систем, который составляет потерю не более $30 \%$ биоорганического потенциала контрольного образца [31]. 
Почвогрунт площадки № 2 также оказался токсичным для микроорганизмов (слой 0-5 см). Однако по сравнению с образцом с площадки № 1 уровень его токсичности был в два раза меньше: снижение почвенного дыхания здесь составило 31\% уровня контроля.

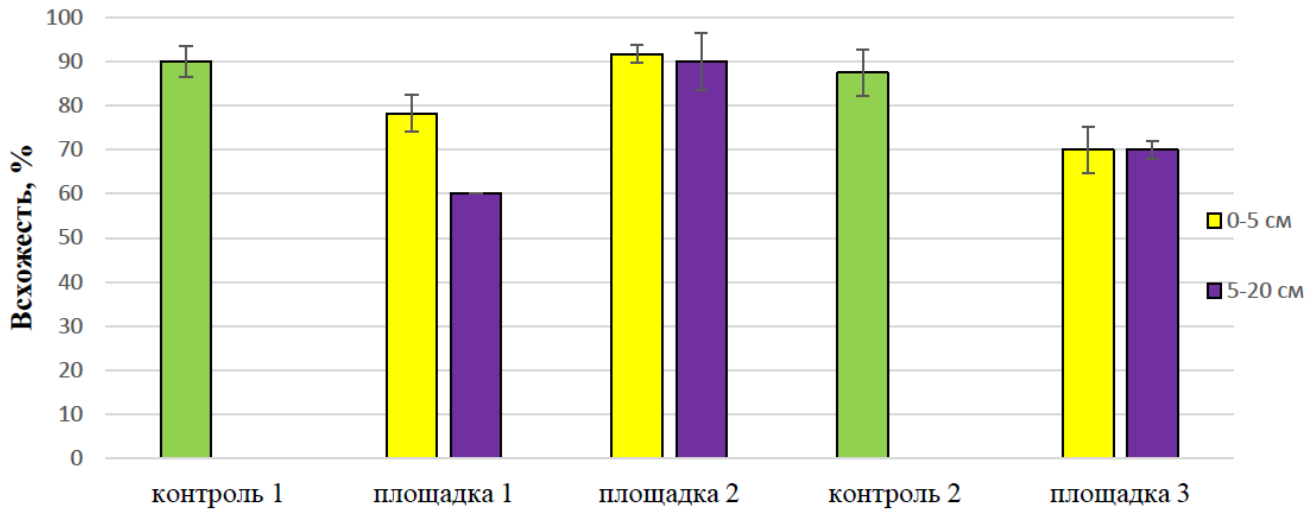

Рис. 2. Результаты контактного биотестирования. Всхожесть семян пшеницы на испытуемых почвогрунтах (глубина 0-5 и 520 см) и контрольном образце (контроль 1 - к площадкам № 1и 2, контроль 2 - к площадке № 3)

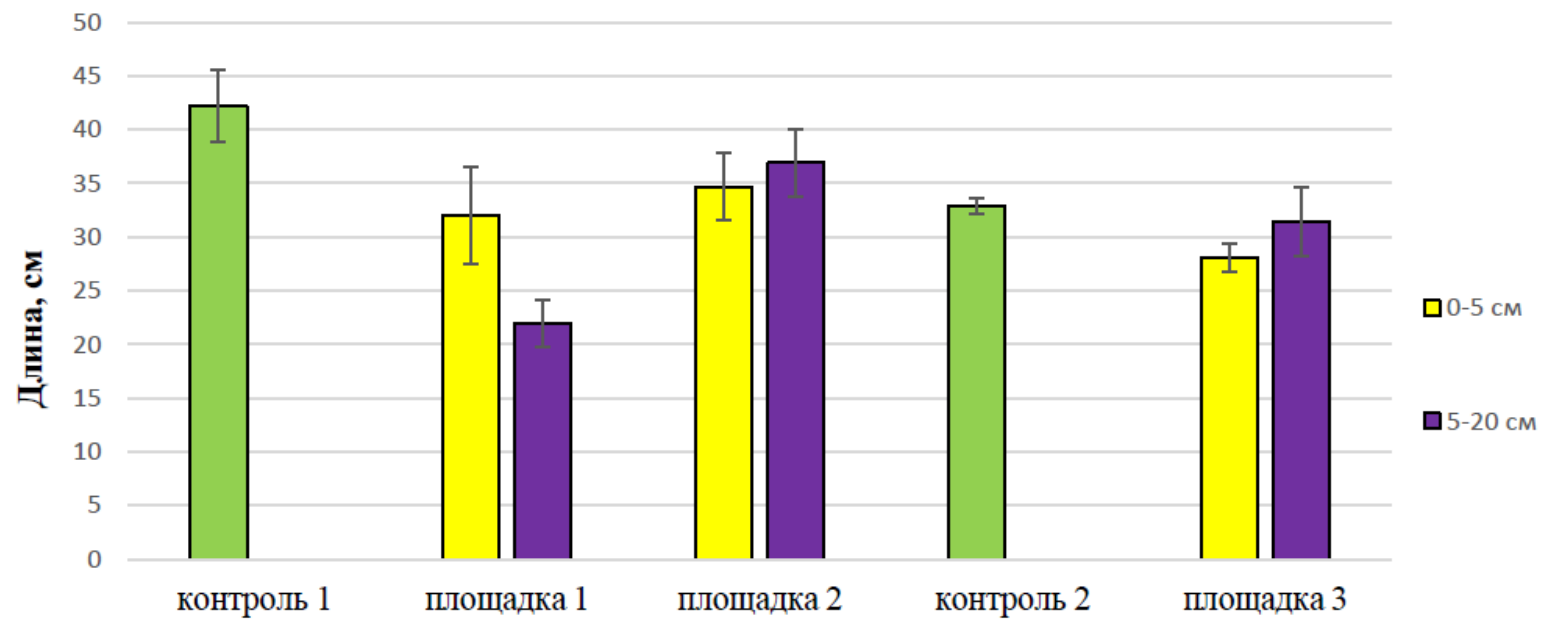

Рис. 3. Результаты контактного биотестирования. Длина корней проросших семян пшеницы на испытуемых почвогрунтах (глубина 0-5 и 5-20 см) и контрольном образце (контроль 1 - к площадкам №№ 1 и 2, контроль 2 - к площадке № 3)

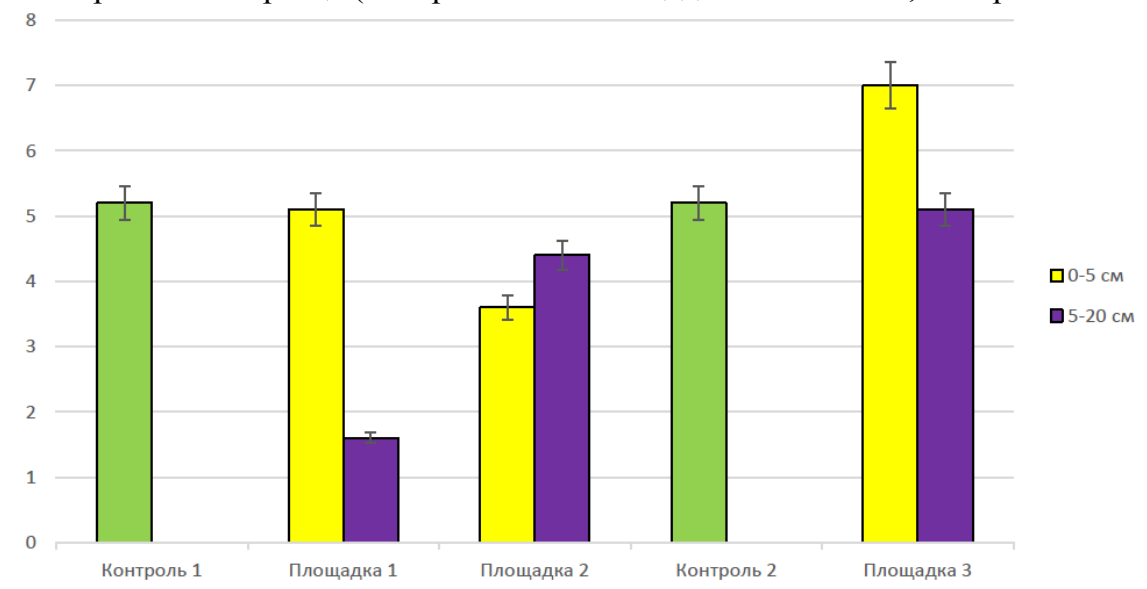

Рис 4. Результаты контактного биотестирования. Дыхание испытуемых почвогрунтов (глубина 0-5 и 5-20 тсм) и контрольного образца, мг СО2/100 г, сутки (контроль 1-к площадке № 1и № 2, контроль 2-к площадке № 3) 
Почвогрунт площадки № 3, как было установлено, не являлся токсичным для природного комплекса микроорганизмов. Более того, на глубине 0-5 см в почвогрунте данной площадки было зафиксировано превышение респираторной активности на $35 \%$ по сравнению с контролем.

Результатам определения ферментативной активности в целом совпали с данными контактного микробного биотеста. Высокая степень токсичности была выявлена на площадках № 1 и 2, где ферментативная активность была подавлена. В почвогрунте площадки № 3 была обнаружена стимуляция протеазной активности, которая составляла $30 \%$ уровня контроля (табл. 4). Таким образом, обобщая результаты микробного теста и изучения ферментативной активности, можно сделать вывод о низкой устойчивости микробоценозов почвогрунтов площадок № 1 и № 2 к токсическому воздействию загрязняющих веществ. Почвогрунт площадки № 3 наоборот оказывал стимулирующий эффект на биохимическую активность микроорганизмов.

Табл. 4

Результаты контактного биотестирования. Протеазная активность почвогрунтов

\begin{tabular}{|c|c|c|}
\hline \multirow{2}{*}{$№$ площадки } & Глубина, см & Протеазная активность $\mathbf{N ,} \%$ от контроля \\
\hline \multirow{2}{*}{1} & $0-5$ & 0 \\
\cline { 2 - 3 } & $5-20$ & 0 \\
\hline \multirow{2}{*}{2} & $0-5$ & 0 \\
\cline { 2 - 3 } & $5-20$ & $30^{\mathrm{a}}$ \\
\hline \multirow{2}{*}{3} & $0-5$ & $31^{\mathrm{a}}$ \\
\hline
\end{tabular}

Результаты всех проведенных биотестов представлены в сводной таблице № 5.

Табл. 5

Интегральная оценка токсичности почвогрунтов

(0 - нет токсичности; I, II и III - уровни токсичности слабый, умеренный и более чем умеренный)

\begin{tabular}{|l|c|c|c|c|c|c|}
\hline \multirow{2}{*}{$\begin{array}{c}\text { № площадки, } \\
\text { глубина, см }\end{array}$} & \multicolumn{2}{|c|}{ Контактное биотестирование } & \multicolumn{3}{c|}{ Элюатное биотестирование } \\
\cline { 2 - 7 } & $\begin{array}{c}\text { Triticum } \\
\text { vulgare L }\end{array}$ & $\begin{array}{c}\text { Микробный } \\
\text { биотест }\end{array}$ & $\begin{array}{c}\text { Протеазная } \\
\text { активность }\end{array}$ & $\begin{array}{c}\text { Daphnia } \\
\text { таgna Straus }\end{array}$ & $\begin{array}{c}\text { Paramecium } \\
\text { caudatum }\end{array}$ & $\begin{array}{c}\text { Chlorella } \\
\text { vulgaris Beijer }\end{array}$ \\
\hline $1,0-5$ & I & 0 & III & 0 & 0 & III \\
\hline $1,5-20$ & II & III & III & 0 & 0 & 0 \\
\hline $2,0-5$ & 0 & III & III & 0 & 0 & III \\
\hline $2,5-20$ & 0 & III & III & 0 & 0 & 0 \\
\hline $3,0-5$ & I & 0 & 0 & 0 & III & III \\
\hline $3,5-20$ & I & 0 & 0 & 0 & 0 & III \\
\hline
\end{tabular}

В почвогрунте площадки № 1 токсичность была установлена с помощью одного элюатного метода на хлорелле, а также тремя контактными методами: фитотест, микробный биотест, определение протеазной активности.

Токсичность почвогрунта площадки № 2 была выявлена с помощью элюатного биотеста на хлорелле и двумя контактными методами: микробный биотест и определение протеазной активности.

Токсичность почвогрунта площадки № 3 выявлялась двумя элюатными методами на хлорелле и инфузориях, а также контактным фитотестом.

Таким образом, по степени токсичности, оцененной суммами уровней токсичности по всем глубинам исследованные почвогрунты можно выстроить в ряд: № $1 \geq$ № $2>$ № 3 .

\section{Заключение}

Результаты химических и физико-химических анализов (нейтральная реакция среды, отсутствие засоления, концентрации тяжелых металлов и органических поллютантов, не превышающие нормативы, и др.) свидетельствовали об отсутствии токсичности в исследованных почвогрунтах рекультивированного карьера.

С помощью методов биотестирования токсичность была выявлена во всех почвогрунтах карьера, так как конечная оценка токсичности почвогрунта должна осуществляться по наиболее чувствительному варианту. Несовпадение данных, полученных с помощью различных методов биотестирования, по всей видимости, объясняется разной чувствительностью используемых тест-культур к разным токсикантам. Исключения составили два контактных метода (микробный биотест и определение протеазной активности), результаты которых в целом совпали.

Среди тест-культур, используемых при проведении элюатного биотестирования, наиболее чувствительной на данном объекте оказалась водоросль хлорелла, значительно меньшей чувствительностью характеризовались инфузории. 
Использование рачков дафний при биотестировании оказалось неэффективным, так как они не реагировали на содержание токсикантов в водной вытяжке.

Контактные методы (метод фитотестирования на пшенице, метод определения протеазной активности и микробный биотест), которые дополняли исследования водных вытяжек, характеризовались одинаково высокой чувствительностью.

Таким образом, впервые для экологического контроля почвогрунтов объектов накопленного экологического ущерба, в частности почвогрунтов, рекультивированных с помощью твердых бытовых отходов в карьерах по выработке глин, были выявлены наиболее эффективные и чувствительные биотесты. Это - элюатный биотест на хлорелле, а также контактные методы биотестирования (фитотест на пшенице, микробный биотест и определение протеазной активности).

Ввиду того, что с помощью аналитических методов не всегда можно выявить токсичность почвогрунтов таких сложных образований, как объекты вторичного накопленного экологического ущерба, для их адекватной экологической оценки наряду с методами химического анализа необходимо всегда использовать методы элюатного и контактного биотестирования.

\section{Список русскоязычной литературы}

\section{ЛИТЕРАТУРА}

1. Бардина ВИ. Применение ферментативного биотеста в биодиагностике почвогрунтов объектов накопленного экологического ущерба. В кн.: Роль почв в биосфере и жизни человека. Материалы докладов международной научной конференции к 100-летию со дня рождения академика Г.В. Добровольского. Москва: МГУ; 2015. С. 150-2.

2. Бардина ТВ, Чугунова МВ, Капелькина ЛП, Бардина ВИ. Биологическая оценка токсичности городских почв в почвенноэкологическом мониторинге. Экология урбанизированных территорий. 2014;2:87-91.

3. Галицкая ПЮ, Селивановская СЮ. Биологическая оценка токсичности почв методом биотестирования. Агрохимия. 2009;3:84-8.

4. Горностаева ЕС, Злобин СС, Сунцова ЕС, Елькина ТС, Домрачева ЛИ, Ашихмина ТЯ. Микробиологический статус почв в зоне действия Кирово-Чепецкого химического комбината. Теоретическая и прикладная экология. 2012;3:90-5.

5. Григорьев ЮС. Новые методы биологического контроля загрязнения окружающей среды. Экопрогресс. 2014;19(2):28-9.

6. Заварзин ГА, Кудеяров ВН. Почва как главный источник углекислоты и резервуар органического углерода на территории России. Вестник Российской Академии наук. 2006;76(1):14-29.

7. Звягинцев ДГ, Бабьева ИП, Зенова ГМ. Биология почв. М.: Изд-во МГУ; 2005.

8. Ибрагимова СТ, Айткельдинова СА, Файзулина ЭР, Саданов АК, Попутникова ТО, Терехова ВА. Экологическая оценка нефтезагрязненных почв Казахстана по откликам стандартных биотест-систем. Доклады по экологическому почвоведению. 2009;11(1):79-94.

9. Ирха Н, Блинова И, Петерселль В. Использование биотестов для оценки влияния почв на снижение токсичности комплексной смеси тяжелых металлов и полициклических ароматических углеводородов. Экологическая химия. 2003;12(4):233-9.

10. Кулибаба ВВ, Петухов ВВ, Зинатулина ЕИ, Меринова ЕС. Рекультивированные карьеры Приневской низменности специфическая разновидность объектов накопленного экологического ущерба. Региональная экология. 2016;43(1):7-13.

11. Мишустин ЕН, Востров ИС. Аппликационные методы в почвенной микробиологии. В кн.: Микробиологические и биохимические исследования почв. Киев; 1971. С. 3-12.

12. Олькова АС. Биотестирование в научно-исследовательской и природоохранной практике России. Успехи современной биологии. 2014;134(6):614-22.

13. Покорна Д, Забранская Д. Сероокисляющие бактерии в экологической технологии. Biotechnology Advances. 2015;33(6):1246-59.

14. Помазкина ЛВ, Семенова ЮВ, Стеренчук АВ. Вклад агроэкосистем в формирование бюджета углерода на территории Иркутской области. Известия Самарского научного центра РАН. 2009;11(1):212-6.

15. Попутникова ТО, Терехова ВА. Установление зоны влияния полигона твердых бытовых отходов на почвы по структурнофункциональным изменениям микробных сообществ. Вестник МГУ Сер. 17. Почвоведение. 2010;2:51-4.

16. Селивановская СЮ, Галицкая ПЮ. Оценка токсичности почв с использованием контактного метода биотестирования. Токсилогический вестник. 2006;4:12-5.

17. Терехова ВА. Биотестирование почв: подходы и проблемы. Почвоведение. 2011;(2):190-8.

18. Терехова ВА. Реализация биотической концепции экологического контроля при почвенно-экологическом нормировании. Использование и охрана природных ресурсов России. 2012;4:31-4.

19. Терехова ВА, Воронина ЛП, Николаева ОВ, Бардина ТВ, Калмацкая ОА, Кирюшина АП, Учанов ПВ, Креславский ВД, Васильева ГК. Применение фитотестирования для решения задач экологического почвоведения. Использование и охрана природных ресурсов в России. 2016;3:37-41.

20. Фокина АИ, Огородникова СЮ, Домрачева ЛИ, Лялина ЕИ, Горностаева ЕА, Ашихмина ТЯ, Кондакова ЛВ. Цианобактерии как тест-организмы и биосорбенты. Почвоведение. 2017;(1):77-85. 
21. Яковлев АС, Евдокимова МВ. Экологическое нормирование почв и управление их качеством. Почвоведение. 2011;(5):582-97.

\section{Общий список литературы/Reference List}

1. Bardina VI. [The use of an enzymatic biotest in biodiagnostics of soil of objects of accumulated environmental damage]. In: Rol' Pochv v Biosfere i Zhizni Cheloveka Materialy Dokladov Mzhdunarodnoy Nauchnoy Konferentsii k 100-letyu so Dnia Rozhdeniya Akademika G.V. Dobrovolskogo. Moscow: MGU; 2015. P. 150-2. (In Russ.)

2. Bardina TV, Chugunova MV, Kapel'kina LP, Bardina VI. [Biological assessment of the toxicity of urban soils in soil-ecological monitoring]. Ekologiya Urbanizirovannykh Territoriy. 2014;2:87-91. (In Russ.)

3. Galickaja PYu, Selivanovskaya SYu. [Biological assessment of soil toxicity by biotesting]. Agrokhimiya. 2009;3:84-8. (In Russ.)

4. Gornostayeva ES, Zlobin SS, Sunctsva ES, Elkina TS, Domracheva LI, Ashihmina TYa. [Microbiological status of soils in the area of the Kirov-Chepetsk Chemical Works]. Teoreticheskaya i Prikladnaya Ekologiya. 2012;3:90-5. (In Russ.)

5. Grigoryev YuS. [New methods of biological control of environmental pollution]. Ekoprogress. 2014;19(2):28-9. (In Russ.)

6. Zavarzin GA, Kudeyarov VN. [Soil as the main source of carbon dioxide and a reservoir of organic carbon in Russia]. Vestnik Rossiyskoy Akademii Nauk. 2006;76(1):14-29. (In Russ.)

7. Zviagintsev DG, Babyeva IP, Zenova GM. Biologiya Pochv. [Soil Biology]. Moscow: MGU; 2005. (In Russ.)

8. Ibragimova ST, Aytkeldinova SA, Fayzulina YeR, Sadanov AK, Poputnikova TO, Terekhova VA. [Ecological assessment of oilcontaminated soils in Kazakhstan according to standard biotest systems responses]. Doklady po Ekologicheskomu Pochvovedeniyu. 2009;11(1):79-94. (In Russ.)

9. Irkha N, Blinova I, Petersell V. [The use of biotests to assess the effect of soils on reducing the toxicity of a complex mixture of heavy metals and polycyclic aromatic hydrocarbons. Ekologicheskaya Khimiya]. 2003;12(4):233-9. (In Russ.)

10. Kulibaba VV, Petukhov VV, Zinatulina EI, Merinova YeS. [Reclaimed quarries of the Prinevskaya lowland: A specific type of objects of accumulated environmental damage]. Regionalnaya Ekologiya. 2016;43(1):7-13. (In Russ.)

11. Mishustin YeN, Vostrov IS. [Application methods in soil microbiology]. In: Mikrobiologicheskiye i Biokhimicheskiye Issledovaniya Pochv. Kiev; 1971. P. 3-12 (In Russ.)

12. Olkova AS. [Biotesting in the research and environmental protection practice of Russia]. Uspekhi Sovremennoy Biologii. 2014;134(6):614-22. (In Russ.)

13. Pokorna D, Zabranskaja D. [Sulfur-oxidizing bacteria in environmental technology]. Biotechnology Advances. 2015;33(6):124659. (In Russ.)

14. Pomazkina LV, Semenova YuV, Sterenchuk AV. [The contribution of agroecosystems to carbon budget formation in the Irkutsk region]. Izvestiya Samarskogo Nauchnogo Tsentra RAN. 2009;11(1):212-6. (In Russ.)

15. Poputnikova TO, Terekhova VA. [Establishment of the zone of influence of the solid waste landfill on soils by structural and functional changes in microbial communities]. Vestnik MGU Ser 17 Pochvovedenye. 2010;2:51-4. (In Russ.)

16. Selivanovskaya SYu, Galickaja PYu. [Assessment of soil toxicity using a contact biotesting method]. Toksilogicheskiy Vestnik. 2006;4:12-5. (In Russ.)

17. Terekhova VA. [Soil bioassay: Approaches and problems]. Pochvovedeniye. 2011;2:190-8. (In Russ.)

18. Terekhova VA. [The implementation of the biotic concept of environmental control in soil-environmental regulation]. Ispolzovanie i Okhrana Prirodnykh Resursov Rossii. 2012;4:31-4. (In Russ.)

19. Terekhova VA, Voronina LP, Nikolayeva OV, Bardina TV, Kalmackaya OA, Kiriushina AP, Uchanov PV, Kreslavskiy VD, Vasilytva GK. [The use of phytotesting to solve the problems of environmental soil science]. Ispolzovaniye i Okhrana Prirodnykh Resursov v Rossii. 2016;3:37-41. (In Russ.)

20. Fokina AI, Ogorodnikova SYu, Domracheva LI, Lialina EI, Gornostayeva EA, Ashikhmina TYa, Kondakova LV. [Cyanobacteria as test organisms and biosorbents]. Pochvovedeniye. 2017;1:77-85. (In Russ.).

21. Yakovlev AS, Yevdokimova MV. Environmental regulation of soils and their quality management. Pochvovedeniye. 2011;5:58297. (In Russ.)

22. Klimkowicz-Pawlas A, Maliszewska-Kordybach B, Smreczak B. Triad-based screening risk assessment of the agricultural area exposed to the long-term PAHs contamination. Environ Geochem Health. 2019;41:1369-85.

23. Alef K. Soil respiration. In: Alef K, Nannipieri P, eds. Methods in Applied Soil Microbiology and Biochemistry. London: Academic Press; 1995. P. 214-9.

24. Bardina TV, Chugunova MV, Kulibaba VV, Polyak YuM, Bardina VI, Kapelkina LP. Applying bioassay methods for ecological assessment of the soils from the brownfield sites. Water Air Soil Pollut; 2017. P. 228-351. DOI: I10.1007/s11270-017-3521-3.

25. Blasé C. Canadian application of microbiotest to assess the toxic potential of liquid and solid media. In: Microbiotests for Routine Toxicity Screening and Biomonitoring. New York: Kluwer Academic; 2000. P. 3-12.

26. Gorbov SN, Bezuglova OS, Yarduni TV, Tagiverdiev SS, Chursinova KV. Soil enzyme activity of urban territories of Rostov agglomeration. Life Sci Jl. 2014;12(12s):605-9. 
27. Matejczyk M, Grazyna AP, Nałecz-Jawecki G, Ulfig K, Markowska-Szczupak A. Estimation of the environmental risk posed by landfills using chemical, microbiological and ecotoxicological testing of leachates. Chemosphere. 2011;82(7):1017-23.

28. Prestes EB, Jonson CM, Castrol VISS, Paraida CCM. Avaliacao daxicidade cronica de piraclostrobin, exoxiconazol e sua inistura em Daphnia similis. Ekotoksikologiya i Zagrjaznenie Okruzhajushhej Sredy. 2013;8(1):113-7.

29. Swiontek Brzezinska M, Burkowska A, Walczak M. Microbial activity in the landfill soil. Prikladnaya Biokhimija i Mikrobiologiya. 2012;48(4):411-6.

30. Terekhova VA, Pukalchik MA, Yakovlev AS. The triad approach to ecological assessment of urban soils. Eurasian Soil Sci. 2014;47(9):952-8. DOI: 10.1134/S1064229314090129.

31. Yakovlev AS, Evdokimova MV. Ecological standardization of soil and soil quality control. Eurasian Soil Sci. 2011;44(5):534-46.



